\title{
Pengembangan Tingkat Pengetahuan Masyarakat Terhadap Lembaga Keuangan Mikro Syariah Di Kampung Sirnagalih Desa Padamulya
}

\section{Developing The Level of Community Knowledge of The Islamic Micro Finance Institutions In Sirnagalih Village Padamulya}

\author{
Enggar Tiasto ${ }^{1}$, Anas Alhifni ${ }^{2}$ \\ ${ }^{1}$ Program Studi Ekonomi Syariah Fakultas Ekonomi Islam Universitas Djuanda Bogor, Jl Tol Ciawi No. 1 \\ Kotak Pos 35 Bogor 16720, e-mail: kangmasenggartiasto@gmail.com \\ 2Program Studi Ekonomi Syariah Fakultas Ekonomi Islam Universitas Djuanda Bogor, Jl Tol Ciawi No. 1 \\ Kotak Pos 35 Bogor 16720, e-mail: alhifniui@gmail.com
}

(Diterima: 25-06-2020; Ditelaah: 15-12-2020; Disetujui: 10-06-2021)

\begin{abstract}
Abstrak
Kegiatan sosialisasi tentang Lembaga Keuangan Mikro Syariah ini dilakukan agar meningkatkan pengetahuan masyarakat terhadap lembaga keuangan berbasis syariah. Potensi masyarakat yang memiliki kinerja kerja dalam lembaga keuangan bisa lebih mengembangkan di dalam lembaga keuangan syariah dan menarik masyarakat agar lebih menumbuhkan minat masyarakat untuk menabung. Metode kegiatan sosialisasi ini dilakukan dengan cara partisipasi aktif mengenai pengenalan Lembaga Keuangan Mikro Syariah untuk dapat direalisasikan dalam kehidupan sehari-hari dan menunjang perekonomian masyarakat untuk memenuhi kebutuhannya. Agar masyarakat terhindar dari sistem ribawi. Hasil dari kegiatan sosialisasi pengenalan Lembaga Keuangan Mikro Syariah adalah meningkatkan pengetahuan masyarakat terhadap lembaga keuangan berbasis syariah.
\end{abstract}

Kata Kunci: Lembaga Keuangan Mikro Syariah, Pengembangan Masyarakat, Sosialisasi

\begin{abstract}
The socialization activities on sharia microfinance institutions were carried out in order to increase public knowledge of sharia-based financial institutions. The potential of people who have work performance in financial institutions can further develop within islamic financial institutions and attact the public to further foster community interest in saving. This method of socialization activities is carried out by means of active participation in the introduction of islamic microfinance institutions to be realized in daily life and to support the economy of the community to meet their needs. So that people avoid the ribawi system. The result of the socialization activity of the introduction of islamic microfinance institutions is to increase public knowledge of islamic based financial institutions.
\end{abstract}

Keywords: Community Development, Islamic Microfinance Institutions, Socialization

\section{PENDAHULUAN}

Lembaga Keuangan Mikro Syariah (LKMS) adalah lembaga keuangan yang usaha pokoknya memberikan kredit dan jasa-jasa lain dalam lalu lintas pembayaran serta peredaran uang yang beroperasi disesuaikan dengan prinsip-prinsip syariah. Dalam pembahasan yang lebih mendalam memahami pengertian lembaga keuangan paling tidak dapat dipahami dari apa yang dikemukakan dalam Kamus Besar Bahasa Indonesia, yang memberi pengertian bahwa Lembaga Keuangan adalah "badan dibidang keuangan yang bertugas menarik uang dan menyalurkan kepada masyarakat". Lembaga Keuangan Syariah adalah badan yang melakukan kegiatan-kegiatan dibidang keuangan dengan menarik uang masyarakat dan menyalurkan uang tersebut kembali ke masyarakat dengan menggunakan 
prinsip syariah. Kata "mikro" penyebutan Lembaga Keuangan Mikro Syariah, memberi pengertian lebih menunjukkan kepada tataran ruang lingkup/cakupan yang lebih kecil. Dengan asumsi perbandingan bahwa lembaga keuangan besar salah satunya adalah berbentuk bank dengan modal berskala besar, maka lembaga keuangan mikro adalah bentukan lain dari bank atau sejenisnya yang mempunyai capital kecil dan diperuntukkan untuk sektor usaha mikro kecil. Dalam pengertian ini dikategorikan kedalamnya biasa dikenal sebagai Baitul Mal Wattamwil (BMT), Koperasi Syariah dan Bank Perkreditan Rakyat Syariah (BPRS). (Lailatul Qadariyah, 2010)

LKMS merupakan lembaga keuangan yang berorientasi pada upaya peningkatan kesejahteraan anggota dan masyarkat. Dengan adanya potensi masyarakat, fungsi dari pada lembaga keuangan mikro syariah ini sangatlah berpotensi sangat besar dapat dikembangkan untuk memperbaiki perekonomian melalui pembiayaan mikro yang ada di Indonesia khususnya di Cianjur Kampung Sirnagalih Desa Padamulya.

Kampung Sirnagalih Desa Padamulya merupakan daerah yang dipilih sebagai tempat untuk pelaksanaan kegiatan pengabdian kepada masyarakat karena daerah tersebut merupakan tempat yang tepat dilihat dari keadaan desa dan keadaan masyarakatnya yang mendukung adanya kegiatan pengabdian ini untuk membantu memberikan solusi dan pemahaman kepada masyarakat dalam hal permasalahan tingkat pengetahuan masyarakat Kampung Sirnagalih Desa Padamulya tentang Lembaga Keuangan Mikro Syariah (LKMS). Pengetahuan masyarakat tentang LKMS masih rendah karena kurangnya pihak yang mensosialisasikan dalam bidang Ekonomi Islam dan kurangnya minat dari masyarakat sendiri untuk mempelajari tentang sistem Lembaga Keuangan Syariah.

Adapun letak wilayah Kampung Sirnagalih yang cukup jauh dari perkotaan menjadi kelemahan masyarakat dalam mendapatkan pengetahuan tentang LKMS. Sehingga dengan keadaan ini membuat pihak yang dapat mensosialisasikan tentang sistem lembaga keuangan syariah. faktor inilah yang menjadikan tingkat pengetahuan masyarakat tentang lembaga keuangan syariah yang masih rendah. Dalam kegiatan pengabdian kepada masyarakat ini akan dilaksanakan kegiatan sosialisasi dalam rangka meningkatkan pengetahuan masyarakat terhadap Lembaga Keuangan Mikro Syariah (LKMS). Kegiatan sosialisasi sangat perlu dilakukan di daerah tersebut mengingat situasi dan keadaan masyarakat yang sangat membutuhkan pihak yang dapat menjelaksan terkait di bidang ekonomi islam ini. Melalui pengabdian kepada masyarakat Kampung Sirnagalih Desa Padamulya ini diharapkan dapat memberikan manfaat pengetahuan bagi masyarakat.

\section{METODE PELAKSANAAN}

Metode pelaksanaan yang digunakan adalah pendekatan partisipatif aktif melalui kegiatan sosialisasi mengenai pengenalan LKMS. Kegiatan sosialisasi dibidang ekonomi syariah ini sebagai ilmu pengetahuan bagi masyarakat. Kegiatan ini dilakukan melalui pendekatan kepada orang-orang dewasa sehingga komunikasi terjalin dengan baik. Kegiatan sosialisasi dilakukan dengan metode ceramah dan diskusi guna menanamkan 
pemahaman tentang Lembaga Keuangan Mikro Syariah. Sosialisasi dilakukan agar meningkatkan pengetahuan terhadap lembaga keuangan mikro syariah.

Lokasi yang dijadikan tempat pelaksanaannya adalah Desa Padamulya, Kecamatan Pasirkuda, Kabupaten Cianjur, Provinsi Jawa Barat. Alasan dipilih Desa Padamulya sebagai karena kategori desa tersebut merupakan desa tertinggal, sehingga memerlukan banyak bantuan untuk mengembangkannya Desa, terutama bantuan Sumber Daya Manusia (SDM) untuk mengembangkan potensi-potensi masyarakat tersebut.

\section{HASIL \& PEMBAHASAN}

Hasil kegiatan sosialisasi Lembaga Keuangan Mikro Syariah (LKMS) yaitu meningkatkan pengetahuan dan pemahaman masyarakat mengenai LKMS dapat dilihat dari respon baik yang di berikan oleh sebagian besar masyarakat terhadap adanya program pengabdian kepada masyarakat yaitu inisiasi pembentukan Lembaga Keuangan Mikro Syariah (LKMS) di Desa Padamulya. Dengan kondisi seperti ini, masyarakat menyadari bahwa pentingnya menggunakan lembaga keuangan yang berbasis syariah sebagai lembaga keuangan yang paling tepat untuk digunakan. Dengan adanya sosialisasi ini, masyarakat dapat membedakan secara jelas antara LKMS dengan lembaga konvensional. Berikut ini dokumentasi kegiatan sosialisasi LKMS.

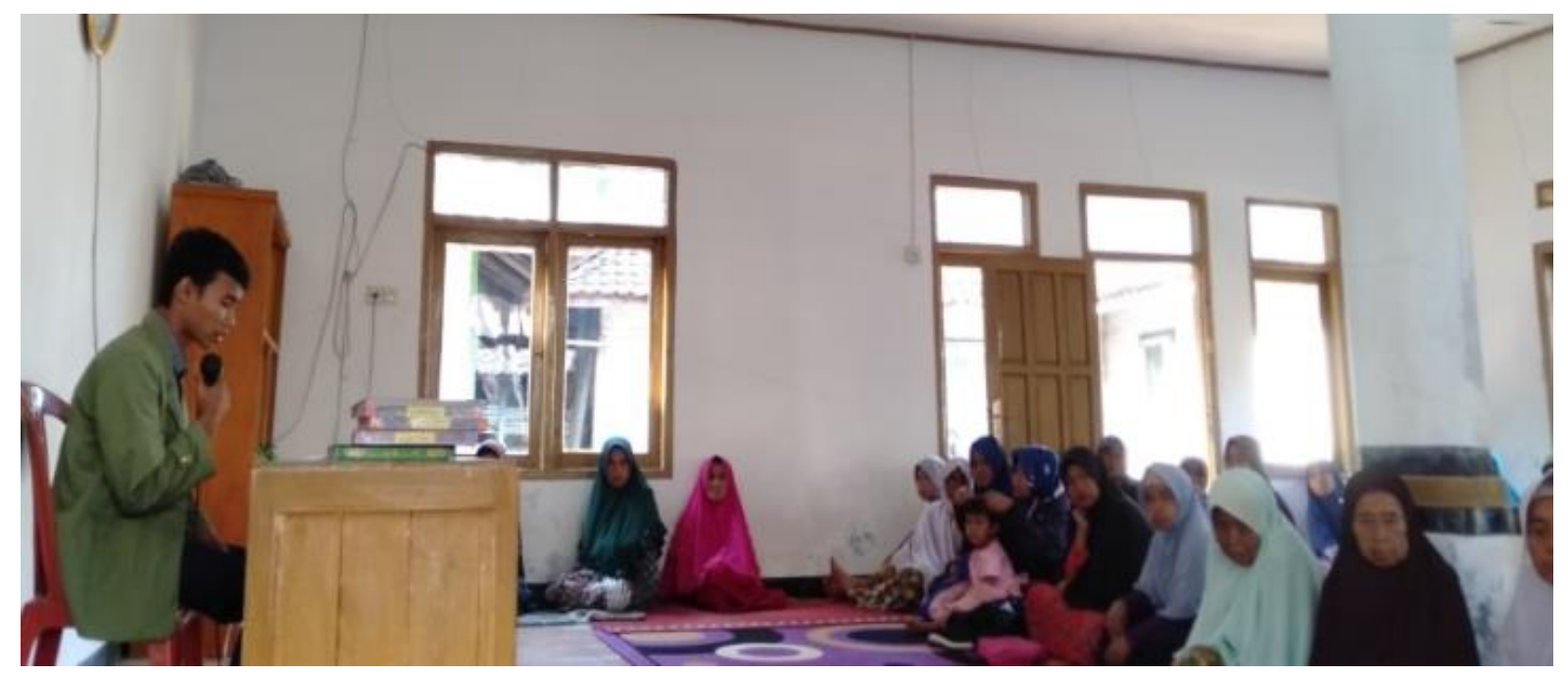

Gambar 1. Pelaksanaan Kegiatan Sosialisasi LKMS

Program kegiatan sosialisasi yang dilakukan berjalan dengan lancar dari rencana yang telah disusun. Untuk dapat mewujudkan keberhasilan ini dibutuhkan anggota yang inisiatif, kreatif dan terampil dalam menjalankan kegiatan tersebut. Diharapkan kepada masyarakat dapat tumbuh berkembang sebagai keberhasilan dalam melaksanakan program kegiatan bersosialisasi ini. Adapun bentuk timbal balik setelah diadakan kegiatan sosialisasi pengenalan LKMS, sebagai berikut:

a. Masyarakat mengikuti dan memberikan respon baik terhadap kegiatan sosialisasi pengenalan LKMS sesuai dengan waktu yang telah ditentukan. 
b. Masyarakat ikut bersama mendukung kegiatan sosialisasi dengan memberikan izin untuk menggunakan Majlis Ta'lim sebagai tempat untuk melaksanakan kegiatan. Sehingga dengan adanya masyarakat di daerah tersebut menjadikan program ini terlaksana sesuai dengan perencanaan awal.

Ketercapaian program merupakan bentuk atau hasil dari pelaksanaan sebuah kegiatan yang dilakukan untuk memberi manfaat bagi orang lain. Adapun bentuk pencapaian dari kegiatan program sosialisasi ekonomi Islam sebagai berikut:

a. Program kegiatan sosialisasi pengenalan LKMS berjalan sesuai dengan perencanaan awal program yaitu pelaksanaan sosialisasi LKMS. Pencapain ini tidak terlepas dari peran berbagai pihak sehingga kegiatan ini terlaksana dengan lancar.

b. Meningkatkan pengetahuan masyarakat tentang bidang ekonomi Islam melaui materi yang disampaikan berupa pembahasan tentang pengenalan LKMS.

c. Target sosialisasi mendekati perencanaan program pengabdian kepada masyarakat Kampung Sirnagalih Desa Padamulya Kecamatan Pasirkuda Kabupaten Cianjur.

Setelah dilakukannya sosialisasi pengenalan LKMS di bidang ekonomi Islam penulis dan masyarakat Kampung Sirnagalih Desa Padamulya akan tetap saling berkoordianasi di dalam sebuah grup (sosial media) untuk saling bertukar pikiran tentang ekonomi Islam. Sehingga pengetahuan masyarakat akan terus meningkat. Maka dari itu, kegiatan sosialisasi pengenalan LKMS diharapkan menjadi solusi permasalahan pengetahuan masyarakat tentang ekonomi syariah dan dengan ilmu pengetahuan yang telah didapatkan mampu merealisasikan dalam kehidupan sehari-hari.

\section{KESIMPULAN}

Kegiatan pengabdian kepada masyarakat yang dilaksanakan di Kampung Sirnagalih Desa Padamulya berjalan dengan lancar dari rencana yang telah disusun. Hambatan yang penulis jumpai saat menjalankan kegiatan tetapi tidak membuat penulis untuk membatalkan kegiatan sosialisasi atau program yang telah direncanakan. Kegiatan sosialisasi ini mendapatkan respon yang baik oleh masyarakat sekitar. Kegiatan sosialisasi ini diharapkan dapat meningkatkan kemampuan masyarakat dalam bidang ekonomi syariah sehingga masyarakat dapat mengembangkan potensi ekonomi yang berada di wilayah tersebut.

Ada beberapa saran yang harus dilakukan, baik dari penulis ataupun pihak-pihak yang terlibat dalam pelaksanaan program, yaitu sebagai berikut: pertama, Kegiatan sosialisasi yang telah di lakukan sebagai pelaksanaan harus senantiasa diawasi dengan adanya koordinasi penulis dengan masyarakat agar lebih meningkatkan pengetahuan masyarakat terhadap ekonomi syariah. Kedua, tokoh agama yang ada di Kampung Sirnagalih Desa Padamulya sebaiknya menambahkan materi pembahasan dalam pengajian mingguan tentang Fiqh Mu'amalah. Hal ini dilakukan agar masyarakat dapat mengetahui secara jelas kegiatan perekonomian yang sesuai dengan prinsip syariah, sehingga praktik ekonomi syariah dapat berkembang di masyarakat. 


\section{DAFTAR PUSTAKA}

Andriani. (2005). Baitul Maal wat Tamwil; Konsep dan Mekanisme di Indonesia. Jurnal Empirisma 14 (2).

Efendi, Jaenal. Mengembangkan Lembaga Keuangan Mikro Syariah, Jurnal Iqtisodia, Jurnal Ekonomi Islam Republika, IPB Bogor, 2010.

Fitriani, W. (2016). Lembaga Keuangan Mikro Syariah: Eksistensi dan Eksesibilitasnya Bagi Pembiayaan Usaha Tani di Sumatra Barat 4.

Huda, Nurul, M. Heykal. (2010). Lembaga Keuangan Islam: Tinjauan Teoritis dan Praktis. Jakarta: Kencana Pranada Media Grup.

Nasrullah, A. (2017). Upaya Peningkatan Partispasi Masyarakat Dalam Penggunaan Produk Dan Jasa Lembaga Keuangan Mikro Syariah (LKMS) Sebagai Salah Satu Pilar Sistem Keuangan Nasional.

Oktafia, R. (2017). Percepatan Pertumbuhan Usaha Mikro, Kecil dan Menengah (UMKM) Melalui Perkuatan Lembaga Keuangan Mikro Syariah (LKMS) di Jawa Timur.

Qadariyah, L., \& Permata , A. R. (2010). Peran Lembaga Keuangan Mikro Syariah Dalam Perekonomian Indonesia

Rusyidianan, A., \& Antonio, M. S. (2016). Peranan Ekonomi Syariah Dalam Pembangunan Daerah. 